family for like experiments on the variability of hybrids, in doing which he came face to face with difficulties in classification needing the eye of a systematist. How these were met, Sir Joseph Hooker, whom he helped in dealing with this order for the Genera Plantarum, and others testify. It is clear that if he multiplied names unduly, he still grouped naturally and truly the allied forms. In the question of hybridity he emphasised abundantly the fact that hybrids frequently have a varying measure of fertility, stating at the same time that in varying they return to the parent forms, and for that reason fail to establish their race-a contention which led to a long controversy.

At this period his work as a gardener came into fruit: the Manuel de l'amateur des jardins, and a connection with the Revue Horticole, Flore des Serres and Le bon Jardinier testify to it. But the neuralgia increased, and drove him to seek an asylum away from work in the Pyrenees, whence in 1878 he was called to take charge of the experimental station known as the Villa Thuret at Antibes.

There, in the pleasant climate of the Mediterranean shore, he experimented in the acclimatisation of such plants as were suitable. Algeria, among French Colonies, needed improved cultivation; and the exigence of Algeria called his attention to the vegetation of dry countries. From Australia he grew Eucalypti and Chenopodiaceae, from South Africa he experimented with Acanthosicyos; and the flowering and fruiting and hybridisation of palms interested him strongly. To these experiments on Australian plants is doubtless due his connection with Sir Ferdinand von Mueller, which led to a joint Manuel de l'Acclimateur.

This must suffice to indicate the direction of his workwork for which the French-speaking people feel a keen gratitude. To us, it is interesting to recall that a few of his later notes appeared in our language in the Gardeners' Chronicle, while two of his earlier papers were considered of sufficient importance to merit translation.

I. H. B.

\section{THE NEW BUILDINGS AT SOUTH KENSINGTON.}

THE foundation stone of the new extension of the Art Museum at South Kensington was laid by Her Majesty the Queen yesterday. When completed, the Museum will be one of the most imposing structures in London, so far as size is concerned. It will have a frontage on Cromwell Road of 700 feet-almost precisely the same frontage as that of the Natural History Museum -and in the Exhibition Road there will be a frontage of 300 feet. The area of the new buildings will be equal to the whole of that covered by the existing Museum, including the temporary sheds on the west side of Exhibition Road.

The Art Museum thus completed is to be called the Victoria and Albert Museum.

The commencement of the new buildings does not directly concern us except that they are complementary to other buildings to be provided for Science on the ground facing the Imperial Institute. It has generally been understood since the Report of the Duke of Devonshire's Commission, which sat about a quarter of a century ago, that a Science Museum was to be built upon this ground. This being so, the building scheme might appropriately have included an Albert Museum for Science as well as a Victoria Museum for Art. But no provision has been made for such a new Science Museum.

According to the Times, the centre of the building which it is proposed to place opposite the Imperial Institute will be occupied by the Science Library, and in the plan given by the Times the proposed buildings are called
"Royal College of Science." But this is not so. The remainder of the frontage will be taken up by chemical and physical laboratories alone; the other departments of the Royal College of Science-astronomical physics, geology, biology, mechanics, mining and metallurgy-will apparently be left in the same unorganised condition as exists at present. It is indeed generally imagined, and it may even be the view of the Chancellor of the Exchequer, that the new buildings are to accommodate all the departments of the Royal College of Science.

We read, for instance, in Tuesday's Times :-

"As regards the Royal College of Science, it will, as already indicated, occupy a position directly facing the Imperial Institute. It is to be of the same length as the Institute, and, in the interests of architectural harmony, it will reproduce several of its leading features. The College will be recessed from the road in the same way; the main entrance of the one will be opposite that of the other, and will be so rounded that between the two a large circular space will be left-in the centre of which a statue may be erected later on-the circle being flanked by the great buildings on each side. The domes or lodges at each extreme of the Imperial Institute will be repeated at corresponding points of the College, and the respective sets connected by a screen across the roadway, thus facilitating passage from one side to the other. The new College of Science will also form a front to the present Science Museum buildings, but there is no idea of the College forming in itself an additional "museum" in the recognised sense of that term. It will rather be devoted to strictly educational purposes, the right wing being occupied by the physical side of the College and the left by the chemical department, while the great laboratories and lecture theatres are to be in the rear, the whole being, further, in direct connection with the present Science Museum."

We repeat, the new so-called "College of Science" will represent only a small portion of the College. That the teaching of some of the subjects now carried on in buildings almost half a mile apart, gains nothing from the new scheme, might perhaps have been borne if it were perfectly certain that ultimately all the teaching would be brought together. But unfortunately this is now very much more unlikely than it has ever been before, unless the Science Museum is to be encroached upon, and its future possibilities of extension for ever wrecked; and the more the architectural effect is to be enhanced by recessing the new buildings from the road, the more, naturally, will the space difficulty be increased for College and Museum alike. We have heard that the plans prepared by the Professors of the Royal College themselves some years ago left the central portion clear primarily for the Museum suggested by the Duke of Devonshire's Commission, the chemical and physical laboratories having their frontage along Prince's Gate. That scheme was far preferable to the present one, so far as providing for the other requirements of both College and Museum are concerned.

In any case it must be acknowledged that the building of the chemical and physical laboratories is only a first step. We shall be glad to know that the future has been considered; and that there already exists a plan showing the condition of things when subsequent stages have been reached, even up to the final one. But we very much doubt whether it has been any one's business to consider any of these things, and responsibility is divided among so many departments that it is scarcely to be wondered at if the future has never been considered at all. But there is one thing greatly to be feared, and it is this. Not only does the plan to be carried out leave the greater part of the teaching in a chaotic state with no chance of betterment while the new buildings are going on; but when they are completed, some future Chancellor 
of the Exchequer may decline further aid on the ground that no representation was made in the present year pointing out the exact state of the case.

It is apparently one of the prices we have to pay for the long neglect of Science in this country, and its small representation among those in political office, that so many arrangements touching our scientific institutions give rise to a hopeless feeling among those who are familiar with both the history and the facts connected with them.

\section{NOTES.}

M. Prillievx has been elected a member of the Paris Academy of Sciences, in succession to the late M. Naudin.

$\mathrm{W}_{\mathrm{E}}$ regret to see the announcement of the death of Sir Frederick McCoy, K.C.M.G., F.R.S., Professor of Natural Sciences in the University, Melbourne.

Mr. W. H. Preece, C.B., F.R.S., has accepted the presidency of the eighteenth Congress of the Sanitary Institute to be held in Southampton from August 29 to September 2.

THE foundation stone of a museum of Oceanography was laid at Monaco on April 25. The museum will contain the collections made by the Prince of Monaco during the expeditions of the yacht Princess Alice. It will contain not only exhibition rooms, but also laboratories for the use of men of science who wish to work upon the collections.

Dr. J. Buckley Bradbury, Downing Professor of Medicine in the University of Cambridge, will deliver the Croonian lectures of the Royal College of Physicians of England in June, on "Some Points in Connection with Sleep, Sleeplessness, and Hypnotics."

WE learn from the Botanical Gazette that the Museum and laboratory building in the New York Botanical Garden is making fair progress towards completion. It is now entirely enclosed, and the partition walls and other rough interior work are nearly finished. It will probably be ready for occupancy late in the spring.

THE Department of Science and Art has received through the Foreign Office an intimation that the Ghent Horticultural Congress has been postponed from June 3 to July 8 .

THE projected expedition of the Duke of the Abruzzi, nephew of King Humbert, to the North Pole is exciting great interest in Italy. A Reuter telegram from Rome states that the Duke, who will be accompanied by three officers of the navy, two sailors, four mountain guides, ten Norwegian sailors, and an Eskimo, will embark about the middle of June at Laurvig, Norway, whence he will proceed to Franz Josef Land, trying to attain as northerly a point as possible. The party will winter in the most northerly port attainable, and will spend enforced leisure in making scientific observations and preparing revictualling stations. In the spring the Duke and his companions will proceed towards the North Pole on sledges drawn by dogs, 120 of which he will embark at Archangel, or, if necessary, in a balloon. The expedition takes two balloons. If all goes well, the Prince will be away some eighteen months. The ship in which the Duke of the Abruzzi will sail is called the Stella Polare.

THE Rev. T. Neville Hutchinson, whose death occurred on May 6, did much to advance the interests of science by his work some years ago as senior science master at Rugby. Forty years ago Rugby was the only public school in which science was taught at all. Harrow and Eton followed, though not with the same liberality as Rugby, where a few years later a special suite of lecture-rooms and laboratories was devoted to science. It was Mr. Hutchinson who reorganised the science work at Rugby in 1870 , and in the first volume of NATURE he described the new laboratories and other buildings erected there for purposes of scientific instruction. Mr. Hutchinson was born in I826. He was second master at King Edward's School, Birming. ham, in $1860-65$, and science master at Rugby from 1865 to I883, when he became vicar of Broadchalke, Wilts. He resigned his vicarage last October, and was made Canon of Salisbury. He was a gifted teacher and lecturer, and old Rugbeians will sincerely regret to learn of his death.

THE death, shortly before completing his sixtieth year, of Mr. Philip Thomas Main, of St. John's College, Cambridge, is announced in the Athenaeum. Mr. P. T. Main published "An Introduction to Plane Astronomy" for University use in 1865, and also assisted his father, the Rev. Robert Main, who was for twenty-five years Chief Assistant at the Royal Observatory, Greenwich, and afterwards for eighteen years Radcliffe Observer at Oxford, in his large work on "Practical and Spherical Astronomy," which appeared in 1863 . Subsequently he turned his chief attention to chemistry, and for many years held the post of superintendent of the laboratory at St. John's College.

THE Council of the British Medical Association desire to remind members of the profession engaged in researches for the advancement of medicine and the allied sciences that they are prepared to receive applications for grants in aid of such re search. Applications for sums to be granted at the next annual meeting must include details of the precise character and objects of the research which is proposed, and must be made on or before June 15 in writing addressed to the General Secretary of the Association. The Council are prepared to receive applications for one of the three research scholarships which is vacant, of the value of $150 l$. per annum, tenable for one year, and subject to renewal by the Council for another year. Appli. cations may also be sent in for a scholarship of $200 l$., for the study of some subject in the department of State Medicine, in memory of the late Mr. Ernest Hart.

THE thirtieth general meeting of the Institution of Mining Engineers will be held in London on May 25. Among the papers to be read, or taken as read, are the following:-Presi. dential address, by Mr. J. A. Longden; alternating currents and their possible applications to mining, Part i., by Mr. Sydney F. Walker ; metric weights and measures, by Mr. J. Emerson Dowson ; Petroleum in Burma, by Dr. Fritz Noetling; mineral resources of Vancouver and adjacent islands, British Columbia, by $\mathrm{Mr}$. Wm. M. Brewer; and a new process of seasoning and preserving timber and other fibrous substances by means of electricity, by Mr. H. Baillie.Weaver.

ARRANGEMENTS are being made for a visit of the Institution of Electrical Engineers to Switzerland in September next. As at present arranged, members will visit the Rheinfelden works on Saturday, September 2, will proceed on the same day to Zürich, and will remain there until September 6. During this time visits will be paid to various industrial works, and to certain power stations and tramway and lighting installations in the district, including, it is hoped, a visit to the Schaffhausen works. The members will then proceed to Lucerne, and, after inspecting the street railways of that town and, if time permit, the Rathhausen works and the Stansstad-Engelberg Railway, will travel, via the Briinig Pass, to Interlaken. Here opportunity will be given for visiting both the Jungfrau Railway (via the Wengern Alp route) and the Burgdorf-Thun Railway, as well as other places of electrical interest in the neighbourhood; and the visit will end on Saturday, September 9. The annual

$$
\text { No. I } 542 \text {, VOL. 6o] }
$$

